4. Штольц К. Ф. Амперометрическое определение ферроцианида в присутствии субклеточных структур / К. Ф. Штольц, И. М. Мосолова, Л. А. Дронова // Биохимические методы. - М. : Наука, 1980. - С. 147-150.

5. Чухрій Б. М. Колориметричний спосіб визначення активності сукцинатдегідрогенази в спермі бугаїв / Б. М. Чухрій, Л. О. Клевець, Д. Д. Остапів // Вісник аграрної науки. -1995. - № 11. - С. 73-75.

6. Chekh B. O. Testing of P-116 based of nano-polymer system containing pseudo polyamino acids / B. O. Chekh, M. Ferens, V. V. Vlizlo // Abstrsctbook for Conference for young scientist. - Kyiv, 2015. - P. 117.

7. Alexander V. Kabanov. Pluronic ${ }^{\circledR}$ block copolymers as novel polymer therapeutics for drug and gene delivery / Alexander V. Kabanov., Elena V. Batrakova., Valery Yu Alakhov // Journal of Controlled Release. - 2002 Vol. 82, № 1. - P. 189-2012.

Чех Богдан, Ференс Марія, Сусол Наталія, Варваренко Сергій, Остапів Дмитро, Влізло Василь. Проникнення в клітини та депонування в організмі щурів нанополімеру GluLa-DPG-PEG600-F. Досліджено нанополімер на основі псевдополіамінокислот GluLa-DPG-PEG600-F. За допомогою люмінесцентної мікроскопії встановлено здатність GluLa-DPG-PEG600-F проникати в клітини (спермії бугаїв), а також депонуватись у тканинах організму щурів за внутрішньом'язового введення. За різних доз полімеру $(0,01,0,05$ та 0,1 мл/мл розрідженої сперми) визначено активність окисно-відновних процесів у сперміях і їх виживання за додавання GluLa-DPGPEG600-F. Нанополімер GluLa-DPG-PEG600-F спроможний зв'язуватися 3 мембранами та проникати в структурні компоненти клітин. При цьому GluLa-DPG-PEG600-F депонується в м'язах дослідних щурів у місці введення за допомогою зв'язування з білками. Вплив нанополімеру GluLa-DPG-PEG600-F на метаболізм клітин (сперміїв бугаїв) за доз 0,01, 0,05 й 0,1 мл/мл розрідженої сперми характеризується зменшеним споживанням кисню на 26; 40 та 56 \% та відновної здатності дихального ланцюга мітохондрій на 73; 80 і 87 \% відповідно.

Ключові слова: спермії бугаїв, лабораторні щурі, нанополімер, псевдополі-амінокислоти, метаболічні процеси.

Чех Богдан, Ференс Мария, Сусол Наталья, Варваренко Сергей, Остапив Дмитрий, Влизло Василий. Проникновение в клетки и депонирование в организме крыс нанополимера GluLa-DPG-PEG600-F. B работе исследуется нанополимер на основе псевдополиаминокислот GluLa-DPG-PEG600-F. C помощью люминесцентной микроскопии установлена способность GluLa-DPG-PEG600-F проникать в клетки (сперматозоиды быков), а также депонироваться в тканях организма крыс. При введения различных доз полимера $(0,01,0,05$ и 0,1 мл/мл разреженной спермы) установлена активность окислительно-восстановительных процессов в спермиях и их выживания. Нанополимер GluLa-DPG-PEG600-F обладает способностью связываться с мембранами клеток и проникать в их структурные компоненты. При этом GluLa-DPG-PEG600-F депонируется в мышцах крыс в месте введения путем связывания с белками. Влияние нанополимера GluLa-DPG-PEG600-F на метаболизм клеток (сперматозоидов быков) при дозах 0,01, 0,05 и 0,1 мл/мл разреженной спермы характеризуется уменьшенным потреблением кислорода на $26 \% ; 40 \%$ и $56 \%$ и восстановительной способности дыхательной цепи митохондрий на $73 \%, 80 \%$ и $87 \%$, соответственно.

Ключевые слова: сперматозоиды быков, лабораторные крысы, нанополимер, псевдополиаминокислоты, метаболические процессы.

Стаття надійшла до редколегії 17.09.2016 р.

УДК УДК 612.017.2+612.146.4+572.783

\author{
Олена Корженевська, \\ Ірина Кофан, \\ Олена Севериновська
}

\title{
Сучасний стан питання щодо проблеми психофізіологічних особливостей працівників залізничного транспорту
}

Питання гігієни розумової праці, установки й психофізіологічної оцінки професійної придатності фахівців до діяльності в середовищі людина-машина в умовах високого нервово-емоційного напруження, монотонії та інших несприятливих чинників є дуже актуальними. Отримані результати дослідження розширюють наявні теоретичні відомості про психофізіологічні особливості працівників залізничного транспорту й можуть використовуватися під час проведення професійного відбору та профілактичного обстеження працівників

(ㄱ Корженевська О., Кофан I., Севериновська О., 2016 
локомотивного депо Придніпровської залізниці, а також у процесі читання лекцій із курсу «Фізіологія праці та спорту» й «Психофізіологія з основами етології».

Ключові слова: професійне навантаження, машиністи локомотива, професійний відбір, психофізіологічні особливості, пам'ять, увага, орієнтація в просторі.

Постановка наукової проблеми та її значення. Останнім часом значно зросла роль проблеми людського фактора щодо всебічного обліку фізичних, фізіологічних, психофізіологічних особливостей і можливостей людини, що розглянуто в контексті системи людина-техніка-середовище.

Розвиток залізничного транспорту призводить до постійного ускладнення системи людина - машина. Існування постійного ризику виникнення транспортних подій у зв'язку зі збільшенням навантажень на людину ставить підвищені вимоги до ії психічних і фізичних можливостей у процесі трудової діяльності $[1 ; 2 ; 4]$.

У зв' язку з цим питання професійного відбору фахівців операторського профілю серед сучасних проблем гігієни й фізіології залишаються актуальними [2; 4]. Потреба подальшої їх розробки зумовлена постійним зростанням важливості професій операторського профілю, а також комплексом соціальноекономічних і медико-біологічних завдань, спрямованих на фізіолого-гігієнічну раціоналізацію умов праці, підвищення безпеки діяльності, профілактику професійно зумовлених захворювань [5].

Професійна діяльність машиніста - це складна комплексна, різноманітна діяльність, що має свою мету, досягнення якої забезпечується використанням усього арсеналу психофізіологічних $\mathrm{i}$ психічних феноменів, що є в розпорядженні осіб. А такий арсенал конкретної людини, звісно, може мати певні індивідуальні особливості, що проявляються в ступені вираженості, розвитку тих чи інших психічних властивостей або особливостей вищої нервової діяльності $[2 ; 6]$.

Упровадження на сучасних локомотивах ускладнених автоматизованих систем зумовило практичну необхідність досліджень, спрямованих на підвищення надійності машиніста-оператора. Однак загалом такі дослідження проводили відповідно до потреб практики. Саме цим пояснюється їх різносторонність щодо надійності, а також незначна їх підпорядкованість загальним вихідним теоретичним концепціям. Емпіричні дослідження значною мірою випередили за темпами й обсягом свого розвитку розробку загальних теоретичних положень проблеми надійності людини як специфічної ланки автоматизованих систем контролю та управління [6].

Робота машиніста ставить високі вимоги до працездатності різних аналізаторів організму, що, насамперед, стосується функції зорового, рухового й слухового. У зв'язку з незначним резервом часу для здійснення управляючих впливів, що пов'язано, зокрема, з об' єктивними обмеженнями величини гальмівного шляху, машиніст повинен на надзвичайно малому відтинку часу не лише сприйняти відповідний сигнал, але й правильно осмислити його, прийняти відповідне рішення та реалізувати його у вигляді потрібного рухового акту [4].

Ураховуючи все вищевикладене, ставимо за мету цієї роботи визначення психофізіологічних особливостей машиністів локомотива.

Методи й матеріали дослідження. Дослідження проводили на базі локомотивного депо Придніпровської залізниці. Усіх досліджуваних розділено на дві групи по 30 осіб у кожній - на контрольну (машиністи-інструктори) та групу спостереження (машиністи, їхні помічники).

Вивчення психофізіологічних особливостей виконували за методиками, заснованими на використанні таблиць Шульте-Платонова, коректурної проби з кільцями Ландольдта та за методикою встановлення просторової орієнтації «годинник із поворотом» [5].

Результати досліджень обробляли статистично за допомогою програм «Статистика» й «Microsoft Excel», достовірність відмінностей у двох незалежних вибірках установлювали за допомогою непараметричного критерію Манна-Уітні.

Виклад основного матеріалу й обгрунтування отриманих результатів дослідження. Аналіз робочого місця машиніста в кабіні локомотива і його оперативної діяльності засвідчив, що рухи, за допомогою яких відбувається управління локомотивом, нескладні й характеризуються мінімальними м' язовими зусиллями. За даними Г. В. Далецького, загальна м'язова робота машиніста при швидкості руху поїзда 100-140 км/год дорівнює 40-50 кгм за 3-6 год роботи. За цей час він виробляє близько 650 незначних за своїми зусиллями рухів. Проте в деяких ситуаціях особливого значення набуває здатність проводити швидкі й точні та керуючі дії. У звичайних умовах дії з управління локомо- 
тивом, зазвичай, складаються 3 декількох комбінацій обмеженої кількості стандартних рухових елементів, не вимагають високої швидкості, точності дозування та значного фізичного зусилля. Їх виконання не потребує психомоторної обдарованості. Однак у низці випадків зоровий контроль за виконанням дій може бути згорнутий і спрощений, оскільки йому перешкоджає напружене «зовнішнє» спостереження, необхідне, зокрема, і для отримання інформації про успішність уже виконуваних керуючих дій [1; 2].

Один із найважливіших показників під час роботи в локомотивній бригаді - стійкість уваги, тобто властивість, яка полягає в тривалому утриманні уваги на предметі чи якійсь діяльності, або тривала та висококонцентрована увага. Ця особливість характеризується часом, упродовж якого діяльність людини зберігає свою цілеспрямованість. Особливо важливе вміння зберігати стійкість уваги за несприятливих умов, за дії різних подразників [2; 3].

Стійкість уваги машиністів і чоловіків, чия праця не пов'язана 3 керуванням локомотивів, має достовірні відмінності, установлені під час обробки даних із таблиць Шульте-Платонова. Так, для

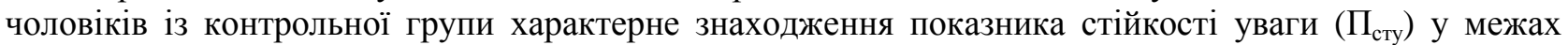

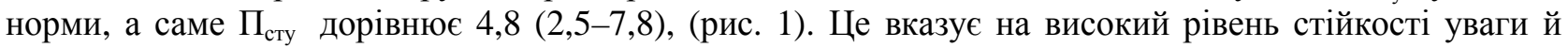
здатність тривалий час зосереджуватися на конкретному об' єкті чи завданні.

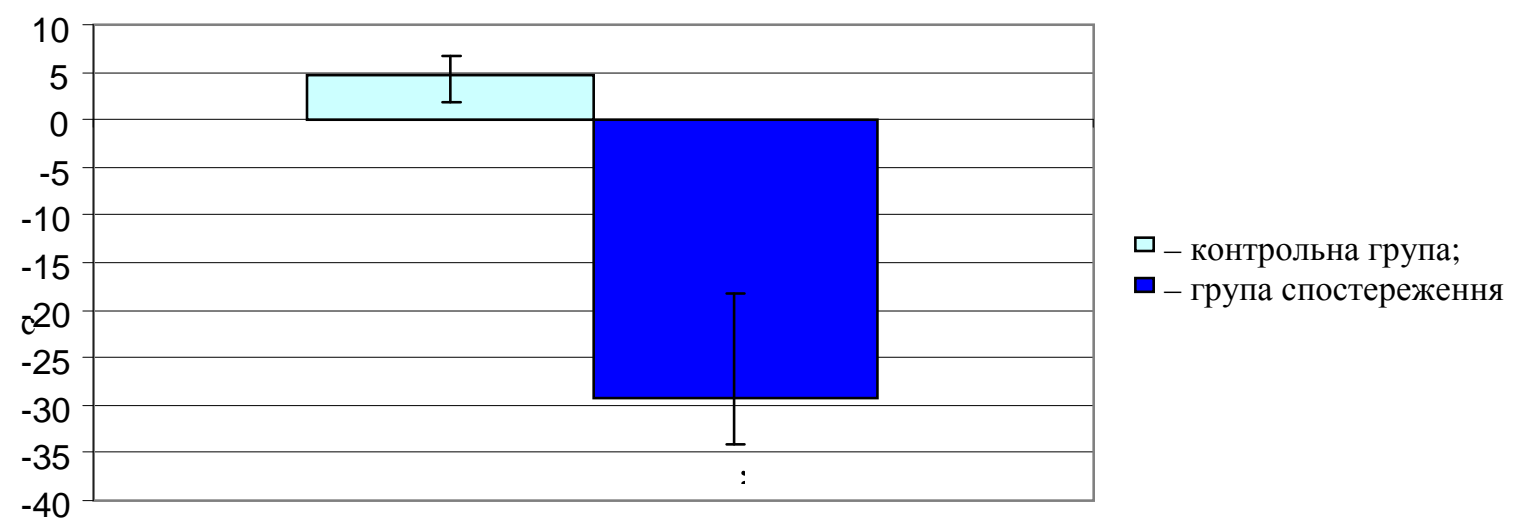

Рис. 1. Показники стійкості уваги контрольної групи та групи спостереження

Примітка. *-Достовірна різниця показників відносно контрольної групи при $P<0,05$.

У машиністів локомотивів депо з групи спостереження значення показника стійкості уваги $\left(\Pi_{\text {сту }}\right)$ достовірно менше, порівняно 3 контрольною групою, та становить - 29,2 (-34; -17,2). Такі дані можуть свідчити про те, що в машиністів локомотивів зі стажем роботи 13-23 роки унаслідок довготривалого фізичного, психологічного й емоційного навантаження знизився рівень стійкості уваги та здатності до концентрації. Можливо, це пов' язано зі зниженням процесів збудження в корі великих півкуль головного мозку як захисної реакції на постійний напружений стан.

На користь такого припущення свідчать і результати проведеної коректурної проби 3 кільцями Ландольдта. За іiі показниками в чоловіків контрольної групи показник стійкості уваги склав 1,06 $(0,85 ; 1,36)$, (рис. 2). Таке незначне відхилення від 1 ще раз підтверджує високий рівень стійкості уваги й здатність довгий час утримувати увагу на будь-якому об' єкті, не відволікаючись і не послаблюючись.

У машиністів локомотивів за результатами коректурної проби простежено перевищення, порівняно 3 нормою, показника стійкості уваги - 1,48 (1; 1,9), (рис 3.2). Таке його значення на $39 \%$ вище за контрольну групу.

Проаналізувавши результати двох методик визначення стійкості уваги, бачимо, що в контрольній групі, у якій чоловіки не мали шкідливих звичок і їхня робота не була пов'язана 3 постійним перенавантаженням, наявний високий рівень стійкості уваги, тобто процеси збудження є стійкими в активних ділянках кори великих півкуль. 


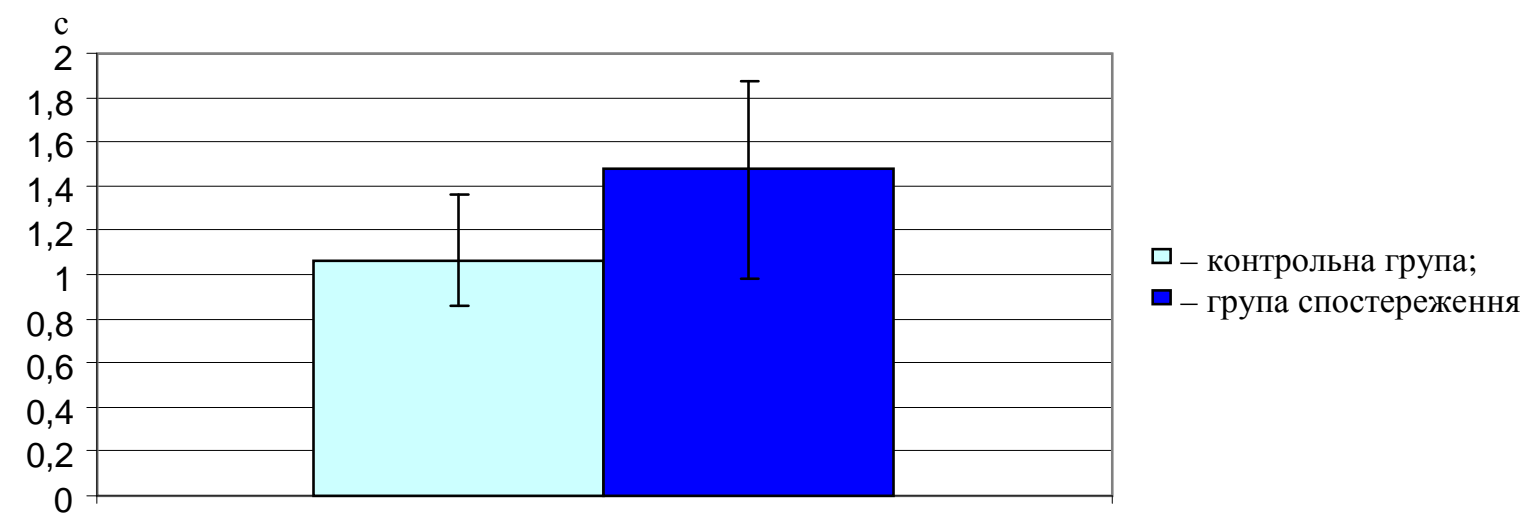

Рис. 2. Показники стійкості уваги (за коректурною пробою з кільиями Ландольдта) осіб контрольної групи та групи спостереження

За двома методиками, у машиністів локомотивів унаслідок стресів та наявності в досліджуваних шкідливих звичок знизився рівень стійкості уваги, тобто змінилася важлива властивість нервової системи - здатність до зосередження на об'єкті, у тому числі знизилося зосередження під час керування локомотивом. Стійкість уваги - необхідна внутрішня умова якісного виконання роботи та збереження безпеки під час руху залізничного транспорту. Фізіологічна основа стійкості уваги відносна сталість та співвідношення процесів збудження й гальмування, які утворюються в корі великих півкуль під впливом певних умов [3; 6]. До цих умов потрібно віднести зміст зовнішніх об'єктів, його багатство, динамічність, силу впливу тощо.

Ще один із найважливіших показників психофізіологічного здоров'я - швидкість переключення уваги, або навмисне її перенесення з одного предмета на інший у результаті діяльності. Фізіологічне підгрунтя переключення уваги - гальмування оптимального збудження в одних ділянках і виникнення його в інших. Переключення уваги з одних об'єктів на інші вимагає належного володіння власною увагою, усвідомлення послідовності дій та операцій із предметами, які потребують опрацювання, уміння керувати власною увагою, що здобувається в процесі діяльності $[1 ; 3 ; 6]$.

Дослідивши переключення уваги за методикою «відшукування чисел із переключенням» у таблицях Шульте-Платонова, отримали такі результати. У контрольній групі показник переключення уваги $\left(\Pi_{\text {пер}}\right)$ склав 80,7 с. $(67 ; 115)$, (рис. 3$)$, тобто перебуває в межах норми та свідчить про високу швидкість переключення уваги. На це вказує й показник часу виконання третього завдання, що склав 281,4 c. $(265 ; 311)$.

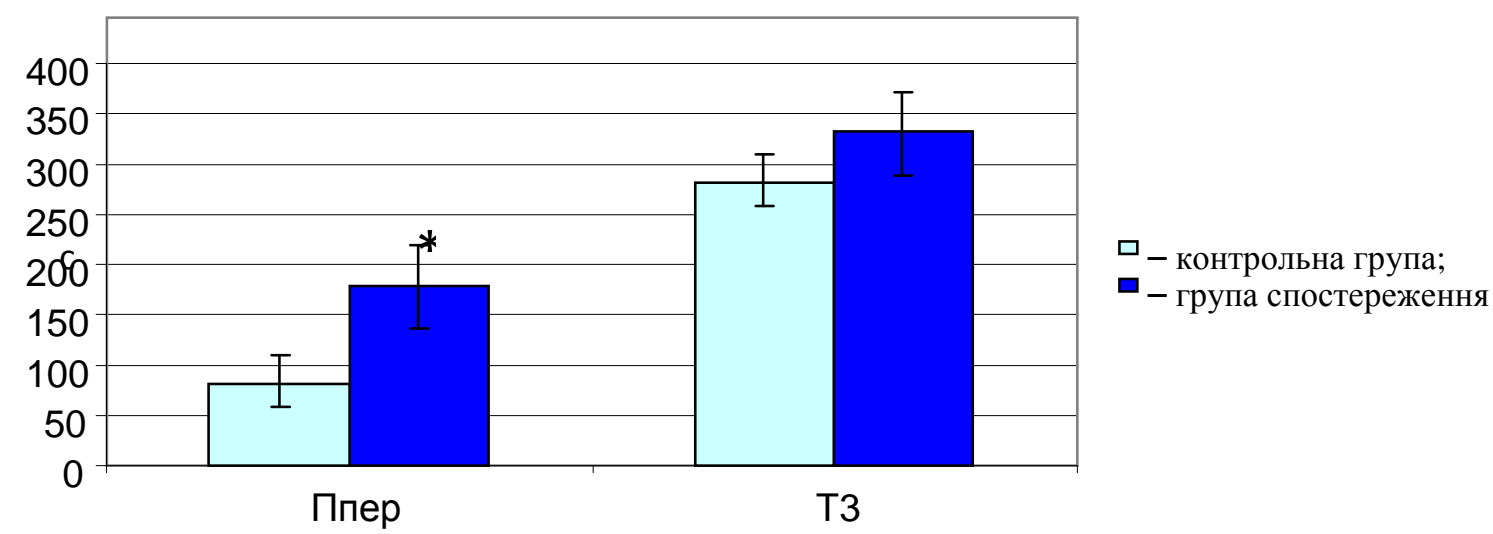

Рис. 3. Показники швидкості переключення уваги в осіб контрольної групи та групи спостереження Примітка. *-Достовірна різниця показників відносно контрольної групи при $p<0,05$. 
Показник швидкості переключення уваги достовірно вищий у машиністів локомотивів відносно контрольної групи, він дорівнює 179,6 с (136,5; 230), що удвічі більше від середніх значень контрольної роботи. Простежено тенденцію до перевищення показника часу виконання третього завдання, Т3 дорівнює 332,1 с (290,1; 377), (рис. 3), що на 18 \% вище, порівняно з показниками контрольної групи. Швидкість переключення уваги перебуває в прямій залежності від рухливості нервових процесів. Саме тому стомлені люди, нервові процеси яких інертні, допускають багато помилок у роботі.

За цими показниками можна зробити висновки, що простежено подібну тенденцію, до стійкості уваги. Швидкість переключення уваги в чоловіків контрольної групи, чия робота не пов'язана 3 постійним фізичним і психоемоційним перенавантаження та які не мають шкідливих звичок, відповідає високому рівню нервових відповідей. Тобто це означає здатність переключення збудження 3 одних активних ділянок на інші ділянки кори великих півкуль. Але бадьорий стан кори забезпечується висхідною й низхідною активуючими ретикулярними системами. Якщо висхідна ретикулярна система, яка несе імпульси до кори головного мозку, лежить в основі біологічно зумовлених форм активації, то низхідна ретикулярна система викликає активуючий вплив імпульсів, які виникають у корі головного мозку, на підкіркові утворення й тим самим забезпечуються вищі форми вибіркової активації, пов’язані зі складними завданнями свідомої діяльності.

У машиністів з групи спостереження швидкість переключення уваги знизилась унаслідок майже 20-річної праці в умовах із вимушеною підвищеною концентрацією уваги та необхідністю іiі переключення 3 одного завдання на інше. Оскільки при керуванні локомотивом машиністу насамперед потрібно забезпечити безпечність руху, а для цього йому необхідне швидке переключення уваги між рухом потяга, контролем за роботою енергосистеми локомотива та розмовами за допомогою радіозв'язку, виконання маніпуляцій на пульті управління. Тому з часом активність нервової системи знизилася, як і швидкість процесів переключення збудження з однієї ділянки головного мозку на іншу. Також можливі негативні зміни в роботі іонної та медіаторної систем, що призводить до зниження швидкості передачі міжсинаптичних імпульсів. Порівняно з контрольною групою, висхідна ретикулярна система повільніше передає імпульси до кори головного мозку, а активуючий вплив імпульсів, які виникають у корі головного мозку, гірше передають імпульс на підкіркові утворення.

Окрім стійкості й швидкості переключення уваги, для продуктивної праці не лише машиністів, а й будь-яких інших працівників локомотивів, потрібна добре розвинена пам'ять. У постійно змінних умовах праці особливо важлива короткочасна пам'ять. У цьому дослідженні ми вирішили розглянути короткочасну зорову й слухову пам'ять як основні види, на які припадає найбільше навантаження, зважаючи на умови праці респондентів.

Проаналізувавши результати визначення короткочасної зорової пам’яті, установили, що для чоловіків контрольної групи притаманний високий рівень зорової пам'яті. У середньому вони правильно відтворили сім $(5 ; 8)$ двозначних чисел із 10 (рис. 4). Для групи спостереження характерно в середньому чотири $(3 ; 6)$ точно відтворених числа. Таке значення показника короткочасної зорової пам'яті найнижче в межах норми й свідчить про середній рівень зорової пам'яті. Подібний стан короткочасної зорової пам'яті в машиністів локомотивів зумовлений постійним перенапруженням зорового аналізатора, оскільки їм доводиться працювати і в нічний час. Також унаслідок понад 20-річного перенавантаження знизився рівень процесів збудження в центральній нервовій системі, а отже, замкнуті нейронні ланцюги, які $є$ структурно-функціональним підгрунтям пам'яті, гірше функціонують. Через шкідливі звички знижується рівень іонів кальцію, який сприяє пролонгуванню дії вивільнення медіаторів, потрібних для запам’ятовування.

Рівень короткочасної слухової пам'яті дуже високий у чоловіків контрольної групи, у середньому вони правильно відтворили вісім (6; 9) двозначних чисел із 10 (рис. 4). Такі результати свідчать про те, що функціональний стан слухового аналізатора й високий рівень активності нейронів центральної нервової системи розвинутий краще, ніж у чоловіків групи спостереження. Іонні та метаболічні зрушення в всьому ланцюгу нейронів, задіяних в обробленні сенсорного стимулу, що надійшов, забезпечують швидке запам'ятовування.

У машиністів локомотивного депо внаслідок систематичного перенавантаження слухового аналізатора та центральної нервової системи знижено показник короткочасної слухової пам’яті. Так, чоловіки групи спостереження в середньому точно відтворили три (2; 5) двозначні числа 310 (рис. 4), що достовірно нижче, порівняно з показником контрольної групи. Отримані данні свідчать про те, що 
внаслідок тривалої праці на важкій і відповідальній посаді машиніста досліджувані чоловіки мають порушення процесів збудження та гальмування в корі великих півкуль головного мозку, також простежено порушення в нейронних пастках (замкнуті нейронні ланцюги) і метаболізмі іонних та медіаторних систем.

Отже, у чоловіків контрольної групи короткочасна зорова й слухова пам'ять, а також зоровий і слуховий аналізатор перебуває в достатньо активному функціональному стані. Нейронні процеси в корі головного мозку відбуваються з високою швидкістю. Добре функціонують нейронні пастки та реверберація нейронних потоків.

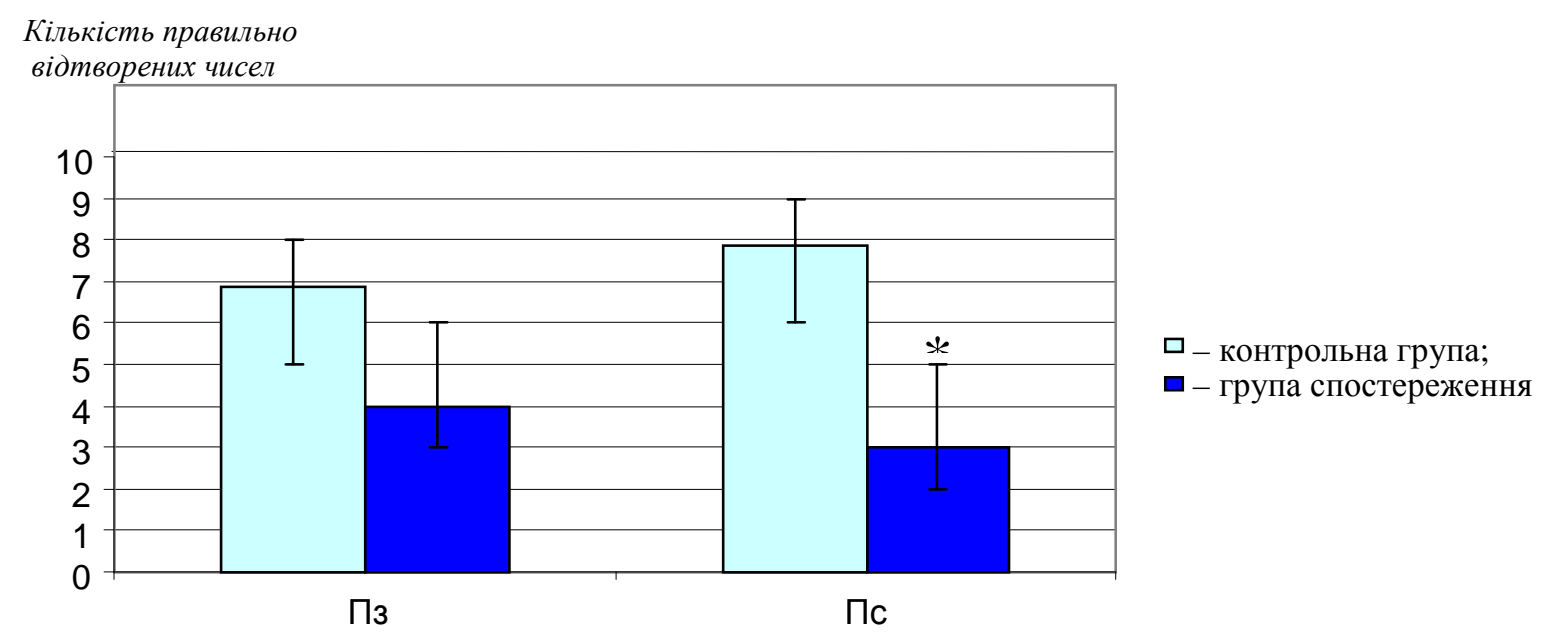

Рис. 4. Показники короткочасної зорової та слухової пам'яті в осіб контрольної групи й групи спостереження

Примітка. *-Достовірна різниця показників, порівняно з контрольною групою при $p<0,05$.

У машиністів із групи спостереження, порівняно з контрольною групою та нормами, вірогідно гірший стан зорової й слухової пам'яті. На такий стан, можливо, уплинуло тривале навантаження на аналізатори та нервову систему в цілому. Постійний стрес виснажує нейронні зв'язки й медіаторні системи, унаслідок чого швидкість передачі міжсинаптичних імпульсів знижується, ослаблюється нейронний зв'язок і реверберація нейронних потоків. Шкідливі звички чоловіків виснажили іонну систему, зокрема знизився рівень іону-кальцію, який сприяе вивільненню медіаторів, тим самим забезпечучи синаптичний зв'язок, необхідний для формування нейронних ланцюгів у корі головного мозку. Такий стан короткочасної пам'яті не прийнятний для працівників такої відповідальної спеціальності, як машиніст локомотива.

Під час керування локомотивом дуже важлива здатність машиніста орієнтуватися в просторі. Вона включає як уявлення про величину й форму, так і просторове розрізнення, i сприйняття простору, $\mathrm{i}$ розуміння різних просторових відносин (визначення положення предмета в просторі між іншими предметами, сприйняття глибини й ін.).

За результатами визначення рівня просторової орієнтації встановили, що в чоловіків із контрольної групи кількість правильних відповідей у середньому становить - $11(9 ; 13)$ iз 13 (рис. 5). Таке значення вказує на високий рівень просторової орієнтації та сприйняття простору, звірення сприйнятого 3 наявними уявленнями й визначення взаємного розташування людини та оточуючих її об’єктів.

У машиністів із локомотивного депо показник просторової орієнтації достовірно нижчий, порівняно 3 контрольною групою, та $\epsilon$ найнижчим у межах норми й становить сім $(5 ; 13)$ правильно встановлених значень часу та шість помилкових (рис. 3-5). Таке значення може свідчити про повільне здійснення процесів сприйняття простору й форм і розмірів об’єктів. Також порушено процеси звірки сприйнятої інформації з наявними уявленнями та визначення взаємного розташування самої людини й оточуючих об'єктів. Оскільки процеси орієнтування формуються на основі умовно-рефлекторної діяльності мозку єдиної для людини система відліку, завдяки якій вона орієнтується, відображає тривимірність простору і являє собою системи напрямків від будь-якої точки відліку, якою може бути 


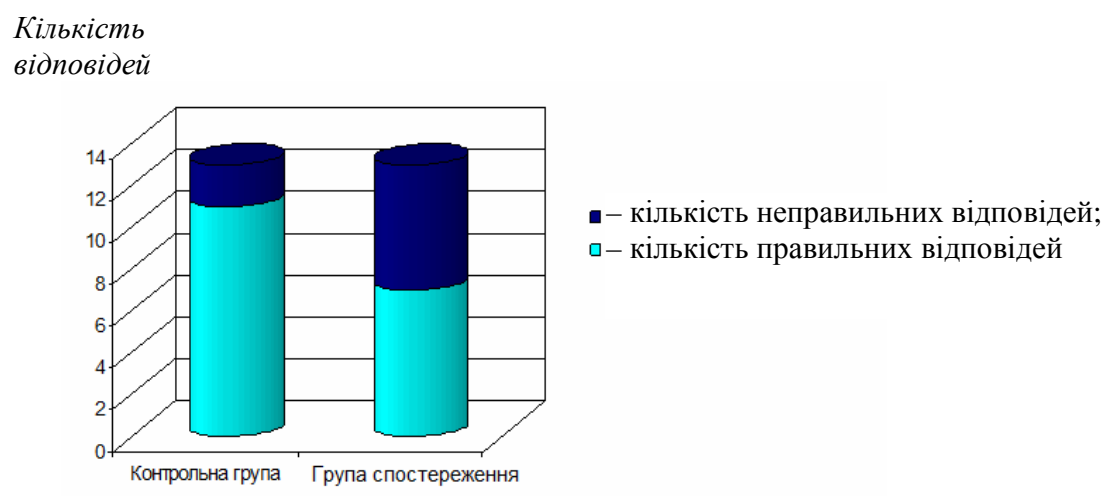

Рис. 5. Показники просторової орієнтації в осіб контрольної групи та групи спостереження

як власне тіло, так і будь-який з оточуючих нас об'єктів. Розрізнення напрямів відбувається через систему відліку - попереду-позаду, праворуч-ліворуч, угорі-внизу й проміжні, що формуються на основі вироблення рухових диференціювань, пов'язаних із показаннями органів чуття. Система відліку утворюється в результаті чуттєвого, практичного розрізнення просторових відносин, за якими згодом закріплюються означення. Орієнтацію в просторі можна визначити як процес виконання трьох завдань, які прийнято називати «вибір напряму», «збереження напряму», «виявлення мети». Розв'язання цих завдань потрібне для орієнтації в будь-якому просторі - для ближньої орієнтації в малому просторі, коли безпосередньо сприймаються орієнтири, визначення підсумкових місць, i для далекої орієнтації у великому просторі, коли орієнтири перебувають поза зоною сприйняття (видимості, чутності, дотику).

Тобто в машиністів із великим стажем роботи в депо просторова орієнтація, як і стійкість та швидкість переключення уваги, короткочасна зорова й слухова пам'ять, гірша, порівняно з відповідними показниками чоловіків контрольної групи. Це ще раз підтверджує негативний вплив стійкого психоемоційного навантаження та низку негативних чинників, притаманних для праці машиніста.

Висновки й перспективи подальших досліджень. Отже, можна зробити висновок, що в цілому психофізіологічний стан машиністів локомотивів $\epsilon$ незадовільним. Тривала робота машиніста як «людська ланка» в системі людина-техніка-середовище виснажила нервові та метаболічні системи. Оскільки ця спеціальність потребує постійної обробки інформації, яка поступає з навколишнього середовища та об'єкта керування, машиніст повинен розподіляти свою психічну діяльність на паралельне виконання різних компонентів діяльності, які міцно пов'язані між собою, центральною нервовою системою людини й сприймаються як різні самостійні види діяльності, котрі відбуваються в корі різних ділянок та потребують активації медіаторних систем. Якщо відбувається погіршення в роботі однієї з функціональних систем організму людини, то знижується продуктивність та якість праці.

У машиністів групи спостереження значення показника стійкості уваги достовірно менше, порівняно з контрольною групою, і становить 29,2 с.

За результатами коректурної проби в осіб групи простежено перевищення відносно норми показника стійкості уваги - 1,48 с. Таке значення показника на 39 \% вище, порівняно 3 контрольною групою.

Дані швидкості переключення уваги достовірно вищі в машиністів локомотивів, порівняно 3 контрольною групою. Цей показник дорівнює 179,6 с, що удвічі більше, ніж у чоловіків контрольної роботи.

У машиністів локомотивів простежено тенденцію до перевищення показника часу виконання третього завдання (Т3 дорівнює 332,1с), що на 18 \% вище, аніж показники контрольної групи.

В осіб групи спостереження знижено показники короткочасної слухової та зорової пам'яті, порівняно з контрольною групи.

У машиністів із локомотивного депо показник просторової орієнтації достовірно нижчий, порівняно 3 контрольною групою, та $\epsilon$ найнижчим у межах норми й становить сім правильно встановлених значень часу й шість помилкових. Таке значення може свідчити про повільне здійснення процесів сприйняття простору та форм і розмірів об’єктів. 


\title{
Джерела та література
}

1. Бодров В. А. Диагностика и прогнозирование профессиональной мотивации в процессе психологического отбора / В. А. Бодров, Л. Д. Сыркин // Психологический журнал. - 2005. - № 1. - С. 73-81.

2. Карцев И. Д. Физиологические механизмы пригодности к профессиям, связанным с возможностью возникновения внезапных сложных ситуаций / И. Д. Карцев, К. Э. Павлович, И. Д. Паронян // Стресс и его патогенетические механизмы. - Кишинев, 1973. - С. 331-340.

3. Коноплянко В. И. Организация и безопасность дорожного движения / В. И. Коноплянко. - М. : Транспорт, 2007. - $383 \mathrm{c}$.

4. Комплекс психофізіологічної діагностики «Діагност-2». Керівництво за експлуатацією ГКТУ.941119.001-2РЕ. - К. : Квант-Транспорт, 2004. - С. 43.

5. Леженкина Татьяна Ивановна. Формирование психологической готовности локомотивной бригады к действиям в опасных ситуациях : дис. ... канд. психол. наук : 19.00.03 / Леженкина Татьяна Ивановна. - М., 2010. - 255 с. : ил. РГБ ОД, 61 10-19/488

6. Нерсесян Л. С. Железнодорожная психология / Л. С. Нерсесян. - 2-е изд., перераб. и доп. / ФГУП Всеросс. институт железнодорожной гигиены Роспотребнадзора, Кафедра железнодорожной гигиены МПФ ППО ММА им. И. М. Сеченова. - М. : ООО Фирма «РЕИНФОР», 2005. - 534 с.

Корженевская Елена, Кофан Ирина, Севериновская Елена. Современное состояние вопроса по проблеме психофизиологических особенностей работников железнодорожного транспорта. Вопросы гигиены умственного труда, установки и психофизиологической оценки профессиональной пригодности специалистов к деятельности в среде человек-машина в условиях высокого нервно-эмоционального напряжения, монотонии, других неблагоприятных факторов является весьма актуальными. Полученные результаты исследования расширяют имеющиеся теоретические сведения о психофизиологических особенностях работников железнодорожного транспорта и могут использоваться при проведении профессионального отбора и при профилактическом обследовании работников локомотивного депо Приднепровской железной дороги, а также при чтении лекций по курсу «Физиология труда и спорта» и «Психофизиология с основами этологии».

Ключевые слова: профессиональная нагрузка, машинисты локомотива, профессиональный отбор, психофизиологические особенности, память, внимание, ориентация в пространстве

Korzhenevska Olena, Kofan Iryna, Severynovska Olena. Modern State of the Issue on the Problem of Workers's Psychophysiological Characteristics of Railway Transport. The hygiene of mental labor, installation and psychophysiological assessment of professional suitability of specialists to activities in the situation of manmachine under high neuro-emotional stress, monotone and other adverse factors that are very important. The obtained results of the experiment expand the existing theoretical data on the physiological characteristics of workers of railway transport and can be used for professional selection and workers's preventive medical examination of the Dnieper railroad locomotive depot and for the course «Physiology of labor and sports» and «Psychophysiology with foundations of ethology».

Key words: professional load, locomotive drivers, professional selection, physiological characteristics, memory, attention, orientation in space.

Стаття надійшла до редколегії 20.09.2016 р.

УДК. 577.597.352.42+547.856.1

\author{
Андрій Безкоровайний, \\ Аліна Зинь, \\ Юлія Лень, \\ Наталія Гарасим, \\ Дмитро Санагурський
}

\section{Ультраструктура зародків в'юна за впливу новосинтезованих амідних похідних 1,4-нафтохінону}

У статті наведено результати досліджень ультраструктури зародків в'юна Misgurnus fossilis L. на стадіях першого та десятого поділів бластомерів у середовищі інкубації з 2-хлоро-3-гідрокси-1,4-нафтохінона та

(C) Безкоровайний А., Зинь А., Лень Ю., Гарасим Н., Санагурський Д., 2016 